\title{
Kemampuan argumentasi mahasiswa melalui model berpikir induktif dengan metode probing-prompting learning
}

\author{
Lisanul Uswah Sadieda ${ }^{1^{*}}$ \\ ${ }^{1}$ Program Studi Pendidikan Matematika, Universitas Islam Negeri Sunan Ampel, Indonesia \\ *Corresponding Author. E-mail: lisanuluswah@uinsby.ac.id
}

\begin{tabular}{ll}
\hline \multicolumn{1}{c}{ ARTICLE INFO } & \multicolumn{1}{c}{ ABSTRACT } \\
\hline Article History: & Penelitian ini bertujuan untuk mendeskripsikan peningkatan kemampuan argumentasi maha- \\
Received: 17 March 2019 & siswa sesudah mengikuti perkuliahan yang menerapkan model berpikir induktif dengan \\
Revised: 28 May 2019 & metode probing-prompting learning pada materi subgrup. Jenis penelitian ini adalah quasi \\
Accepted: 22 June 2019 & eksperimen dengan pendekatan kuantitatif. Sampel penelitian adalah 38 mahasiswa angkatan \\
& 2016/2017 Prodi Pendidikan Matematika UIN Sunan Ampel Surabaya. Instrumen yang digu- \\
& nakan adalah lembar tes kemampuan argumentasi. Kemampuan argumentasi mahasiswa \\
Keywords: & diidentifikasi berdasarkan komponen argumentasi McNeill dan Krajcik yang terdiri dari claim, \\
Model berpikir induktif & evidence, reasoning, dan rebuttal. Peningkatan kemampuan argumentasi mahasiswa dianalisis \\
Probing-prompting & dengan statistik non parametrik menggunakan uji Wilcoxon Signed-Rank pada taraf signifikan \\
learning & 5\% ( $\alpha=0,05)$. Hasil analisis data menunjukkan bahwa kemampuan argumentasi mahasiswa \\
Argumentasi & setelah perlakuan lebih baik dibandingkan sebelum perlakuan dan terdapat perbedaan signi- \\
Subgrup & fikan (Z=-7,397, $p=0,000)$ kemampuan argumentasi mahasiswa sebelum dan setelah diterap- \\
Inductive thinking model & kan model berpikir induktif dengan metode probing-prompting learning pada materi subgrup. \\
Argumentation & Dengan demikian, penerapan model berpikir induktif dengan metode probing-prompting \\
& learning pada materi subgrup efektif untuk meningkatkan kemampuan argumentasi maha- \\
& siswa.
\end{tabular}

This study aimed to describe an increase in students' argumentative abilities after attending lectures that apply inductive thinking models with probing-prompting learning methods in subgroup material. This type of research was quasi-experimental with a quantitative approach. The study sample was 38 students of Mathematics Education Department of State Islamic University Sunan Ampel Surabaya, Indonesia. The instrument used was the argumentation ability test sheet. The student's argumentation ability was identified based on McNeill and Krajcik's argumentation component consisting of claims, evidence, reasoning, and rebuttal. Improved student argumentation skills were analyzed by non-parametric statistics using the

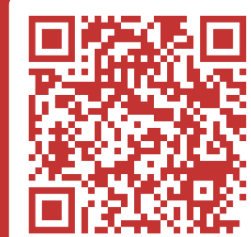

Scan me Wilcoxon Signed-Rank test. The results of data analysis showed that the students' argumentation ability after treatment was better than before treatment and there was a significant difference $(Z=-7,397, p=0,000)$ the ability of students' argumentation before and after the inductive thinking model with the probing-prompting learning method was applied in the subgroup material. Thus, the implementation of inductive thinking models with probing prompting learning methods in subgroup material was effective for improving students' argumentation abilities. This is an open access article under the CC-BY-SA license (c) \section{.}

\section{How to Cite:}

Sadieda, L. U. (2019). Kemampuan argumentasi mahasiswa melalui model berpikir induktif dengan metode probing-prompting learning. PYTHAGORAS: Jurnal Pendidikan Matematika, 14(1), 23-32. doi: https://doi.org/10.21831/pg.v14i1.24038 


\section{PENDAHULUAN}

Matematika adalah pengetahuan tentang struktur-struktur yang logis. Struktur dalam matematika memiliki pola bepikir deduktif yang secara umum tersusun atas konsep primitif (undefined term), aksioma-aksioma, konsepkonsep lain yang didefinisikan serta teorema-teorema. Unsur yang terakhir yaitu konsep-konsep lain yang didefinisikan serta teorema-teorema, dapat dinyatakan dalam bentuk lemma, corollary, maupun kriteria (Soedjadi, 1998). Suatu teorema, lemma, corollary maupun kriteria tidak selalu ditemukan melalui pemikiran deduktif, namun dapat juga diperoleh melalui langkah-langkah induktif dari pengalaman lapangan atau data empirik. Akan tetapi kebenarannya harus dapat dibuktikan secara deduktif menggunakan aksioma, teorema dan definisi terdahulu yang telah diterima sebagai benar dalam strukturnya. Hal ini sesuai dengan pendapat Bell (1981) yang menyatakan bahwa argumen deduktif merupakan metode yang dapat diterima dalam pembuktian matematika. Suatu argumen dikatakan valid jika argumen tersebut didasarkan atas prinsip-prinsip implikasi yang diterima dan termuat dalam suatu sistem logika formal. Pada akhirnya bukti yang memuat argumen-argumen deduktif tersebut harus dapat meyakinkan orang lain akan kebenaran pernyataan atau teorema yang ditemukan.

Apa yang telah dikemukakan sebelumnya menunjukkan bahwa bukti (proof) berfungsi sebagai verifikasi dari kebenaran pernyataan-pernyataan matematika. Selain itu, bukti juga dapat berfungsi untuk menemukan dan menciptakan konsep matematika baru. Bukti dapat menjadi suatu konsep ketika dapat digunakan sebagai hasil yang pasti pada teorema selanjutnya tanpa perlu memecahnya menjadi langkah-langkah tersendiri (Chin, 2003). Suatu bukti juga dapat berfungsi untuk mengkomunikasikan konsep matematis serta mengorganisasikan pernyataan-pernyataan secara sistematis dalam sistem aksiomatik (Huang, 2005). Oleh karena itu, pembuktian matematis merupakan salah satu aspek yang sangat penting dalam matematika formal.

Kemampuan argumentasi yang baik tentunya sangat dibutuhkan dalam proses penyusunan bukti matematis. Argumentasi diartikan sebagai "the statement of a point of view and the evidence that supports it in a way intended to be persuasive to other people" (Ruggiero, 2009). Jadi pada dasarnya argumentasi merupakan suatu pernyataan yang didukung oleh data dan fakta yang objektif sehingga dapat digunakan untuk mengubah atau mempengaruhi pikiran orang lain. Sedangkan Shirley, Erduran, dan Osborne (2006) mendefinisikan argumentasi sebagai proses mengumpulkan berbagai komponen yang dibutuhkan untuk membangun suatu pendapat (argumen).

Komponen argumentasi menurut Toulmin terdiri dari claim, evidence, warrant, backing, qualifier, dan rebuttal (Tristanti, Sutawidjaja, As'ari, \& Muksar, 2015). Sedangkan komponen argumentasi menurut McNeill dan Krajcik (2011) terdiri dari: claim, evidence, reasoning dan rebuttal. Claim merupakan jawaban dari suatu permasalahan. Evidence adalah sebuah data pendukung atau informasi yang mendukung sebuah claim yang dapat diperoleh dari penyelidikan atau pengamatan, informasi yang ditemukan dalam teks, data yang diarsipkan, ataupun informasi dari seorang ahli. Reasoning adalah penjelasan tentang bagaimana bukti dapat mendukung claim yang diajukan sekaligus dapat mengajak atau menyakinkan orang lain untuk mendukung claim berdasarkan bukti yang ada. Sedangkan rebuttal menggambarkan penjelasan alternatif atau menyediakan bukti kontra dan penalaran mengapa alternatif tersebut tidak tepat.

Komponen argumentasi Toulmin maupun McNeill dan Krajcik merupakan struktur dasar argumentasi yang mampu meningkatkan kemampuan argumentasi secara lisan dan tertulis. Argumentasi tertulis bermanfaat untuk meningkatkan pengetahuan ilmiah dan kemampuan menulis siswa (Meghan, Crowell, Schunn, Cannady, \& Dorph, 2015). Sedangkan argumentasi lisan bermanfaat untuk melatih dan meningkatkan kemampuan berbicara atau kemampuan mengungkapkan apa yang ada di benaknya berdasarkan informasi atau data yang telah diperoleh (Meghan et al., 2015). Dengan demikian, baik secara lisan maupun tertulis, kamampuan argumentasi penting dikuasai oleh siswa, terutama untuk meningkatkan pemahaman mereka terhadap suatu konsep matematika.

Kemampuan argumentasi mahasiswa yang hendak diteliti dalam penelitian ini yaitu terkait dengan kemampuan argumentasi mahasiswa untuk memecahkan masalah pembuktian pada materi subgrup. Subgrup merupakan salah satu konsep yang termuat dalam kajian mata kuliah struktur aljabar atau aljabar abstrak, khususnya konsep teori grup. Pemilihan konsep ini sebagai materi penelitian karena memang dalam menempuh matakuliah ini mahasiswa dituntut memiliki kompetensi untuk mampu menyusun bukti yang valid dan tepat untuk membuktikan pernyataan-pernyataan menggunakan aksioma, definisi dan teorema yang ada dalam teori grup.

Fakta di lapangan menunjukkan bahwa penguasaan mahasiswa terhadap materi ini masih rendah. Menurut data yang peneliti peroleh selama mengampu mata kuliah ini, mahasiswa yang memperoleh nilai antara A sampai dengan B hanya terdapat 22\% pada tahun akademik 2013/2014, 34\% pada tahun akademik 2014/2015, 21\% pada 
tahun akademik 2015/2016, dan 32\% pada tahun akademik 2016/2017 (Siakad UIN Sunan Ampel, 2017). Kondisi ini menunjukkan bahwa mayoritas mahasiswa Program Studi Pendidikan Matematika Universitas Islam Negeri Sunan Ampel masih kesulitan dalam melakukan pembuktian pernyataan-pernyataan matematis yang menjadi fokus utama perkuliahan ini. Secara tidak langsung hal ini juga mengindikasikan kurangnya kemampuan mahasiswa dalam pengajuan argumentasi.

Fakta yang telah dikemukakan sebelumnya relevan dengan pendapatZeidler (1997) yang menyatakan bahwa mahasiswa masih mengalami kesulitan dalam melakukan pengajuan argumentasi sebagai fondasi berpikir kritis dan logis. Stein dan Bernas (1999) menemukan bahwa kelemahan paling umum yang dialami mahasiswa dalam pengajuan argumentasi ialah kurangnya kemampuan dalam memberikan kontra-argumentasi. Ketika seorang mahasiswa diminta memberikan argumen untuk mendukung atau menentang suatu pernyataan, pada umumnya akan lebih banyak memberikan bukti-bukti yang mendukung suatu pernyataan dibandingkan memberikan sanggahan. Mahasiswa jarang mengajukan sanggahan dalam analisis argumentasi matematika, padahal hal itu terbukti berguna dalam analisis argumentasi yang mereka sampaikan (Inglis, Ramos, \& Simpson, 2007).

Kesulitan mahasiswa dalam menyusun argumentasi dari suatu permasalahan salah satunya disebabkan proses perkuliahan yang belum memfasilitasi mahasiswa untuk berusaha mengemukakan argumentasi kritisnya. Pembelajaran matematika di tingkat perguruan tinggi masih ada yang menitikberatkan pada penyelesaian masalah tanpa memberi porsi lebih kepada mahasiswa untuk mengungkapkan bagaimana cara mendapatkan data yang relevan dengan permasalahan yang dihadapi, bagaimana cara mendapatkan definisi atau teorema yang bisa digunakan, sanggahan apa yang dapat dilakukan, serta bagaimana menentukan klaim yang tepat (Newton, Driver, \& Osborne, 1999). Dengan demikian diperlukan suatu inovasi pembelajaran yang dapat memfasilitasi mahasiswa dalam mengembangkan kemampuan argumentasinya.

Beberapa penelitian yang bertujuan untuk menemukan model pembelajaran yang sesuai untuk mengatasi permasalahan tersebut juga telah dilakukan. Soekisno (2015) mencoba menerapkan pembelajaran berbasis masalah untuk meningkatkan kemampuan argumentasi mahasiswa pada materi Kalkukus 1. Farida dan Gusniarti (2014) menerapkan pembelajaran inkuri argumentatif untuk mengembangkan keterampilan argumentasi siswa. Hasil penelitian keduanya menunjukkan adanya perubahan positif kemampuan argumentasi subjek penelitian setelah mengikuti pembelajaran menggunakan kedua model pembelajaran tersebut. Proses pembelajaran kedua model pembelajaran tersebut pada umumnya dimulai dengan penyajian masalah nyata yang diselesaikan secara nyata melalui observasi dan pengumpulan data, pengolahan data, penarikan kesimpulan sampai dengan proses pembentukan konsep. Proses pembelajaran tersebut akan membantu peserta didik memahami konsep bukan sekedar menghafal konsep. Pemahaman konsep yang baik akan membantu peserta didik untuk menggunakan konsep yang mereka miliki dalam situasi baru, termasuk dalam mengajukan suatu argumen. Oleh karena itu, untuk meningkatkan kemampuan argumentasi mahasiswa pada materi subgrup, peneliti juga memilih pembelajaran yang menghendaki mahasiswa membangun konsep melalui penyelidikan secara terbimbing, yaitu menggunakan model berpikir induktif.

Pemilihan model berpikir induktif ini didasari oleh hasil penelitian dari Sumaryati dan Sumarmo (2013) yang menunjukkan bahwa pemahaman dan kemampuan berpikir kritis matematis siswa yang mengikuti pembelajaran menggunakan pendekatan induktif-deduktif lebih baik dibandingkan yang mengikuti pembelajaran biasa. Di sisi lain Ennis (1981) menyatakan bahwa kemampuan berpikir kritis berkorelasi dengan kemampuan argumentasi seseorang. Dengan demikian, mengacu pada kedua pendapat tersebut, memperkuat dugaan bahwa model berpikir induktif memang sesuai untuk meningkatkan kemampuan argumentasi peserta didik.

Model pengajaran berpikir induktif sendiri didasarkan pada asumsi bahwa setiap manusia, termasuk siswa merupakan konseptor alamiah yang setiap saat melakukan konseptualisasi, membandingkan dan membedakan objek atau kejadian (Huda, 2017). Model ini sangat sesuai untuk membantu mahasiswa dalam mengkonstruksi suatu konsep sekaligus menerapkan konsep yang ditemukan, karena sintak pembelajarannya dimulai dari pengklasifikasian contoh-contoh suatu konsep, membuat relasi antar kategori sampai dengan tahap pengujian kebenaran prediksi. Pada tahap terakhir inilah kemampuan argumentasi mahasiswa akan dilatihkan. Mahasiswa akan diminta untuk memprediksi atau menyusun hipotesis dari suatu permasalahan, menjelaskannya, kemudian menguji kebenaran dari prediksi yang telah dibuat.

Model berpikir induktif ini akan lebih efektif jika dikombinasikan dengan metode probing-prompting learning. Pemilihan metode ini didasari oleh hasil penelitian Gumelar (2016) yang menunjukkan bahwa terdapat perbedaan 
yang signifikan antara kemampuan menulis argumentasi sebelum dan sesudah mengikuti pembelajaran menggunakan metode probing-prompting learning. Metode probing-prompting learning adalah pembelajaran dengan menyajikan serangkaian pertanyaan yang sifatnya menuntun dan menggali gagasan siswa sehingga dapat meningkatkan proses berpikir yang mampu mengaitkan pengetahuan dan pengalaman mahasiswa dengan pengetahuan baru yang sedang dipelajari (Huda, 2017). Pertanyaan-pertanyaan tersebut dapat membimbing mahasiswa untuk melihat hubungan antar konsep, aksioma dan teorema, sekaligus mendorong mahasiswa untuk mengembangkan kemampuannya dalam menyusun argumentasi. Proses tanya jawab dalam pembelajaran dilakukan dengan menunjuk mahasiswa secara acak, sehingga setiap mahasiswa mau tidak mau harus berpartisipasi aktif dan fokus perhatian mereka akan terjaga karena harus selalu siap dengan jawaban dari pertanyaan yang diajukan.

Berdasarkan permasalahan yang telah dikemukakan dan kajian teori yang telah diuraikan sebelumnya, diduga bahwa penerapan model berpikir induktif dengan metode probing-prompting learning dapat mengatasi permasalahan terkait rendahnya kemampuan argumentasi mahasiswa. Dengan demikian, secara spesifik penelitian ini bertujuan untuk mendeskripsikan peningkatan kemampuan argumentasi mahasiswa setelah mengikuti perkuliahan yang menerapkan model berpikir induktif dengan metode probing-prompting learning pada materi subgrup. Hasil penelitian ini diharapkan dapat memberikan sumbangan terhadap best practice pada pembelajaran matematika, khususnya pada jenjang perguruan tinggi.

\section{METODE}

Penelitian ini merupakan penelitian quasi eksperimen dengan pendekatan kuantitatif. Populasi dalam penelitian ini adalah seluruh mahasiswa angkatan 2016/2017 pada Program Studi Pendidikan Matematika, Universitas Islam Negeri Sunan Ampel Surabaya, Indonesia, yang sedang mengambil mata kuliah aljabar abstrak. Sampel penelitian adalah mahasiswa kelas A yang dipilih menggunakan teknik purposive sampling. Kelas A dipilih karena merupakan satu-satunya kelas yang diampu oleh peneliti. Hal ini bertujuan agar eksperimen penerapan model pembelajaran berjalan lancar sesuai dengan desain pembelajaran dan prosedur penelitian yang dirancang oleh peneliti. Jumlah mahasiswa pada kelas A tersebut sebanyak 38 orang, namun karena pada pelaksanaan tes kemampuan argumentasi awal ada 1 orang yang tidak hadir, maka untuk analisis data kemampuan argumentasi mahasiswa hanya menggunakan data dari 37 mahasiswa saja.

Perangkat pembelajaran yang disusun dalam penelitian ini adalah Satuan Acara Perkuliahan (SAP) dan Lembar Kegiatan Mahasiswa (LKM). Langkah-langkah perkuliahan dalam SAP didesain sesuai dengan sintaks model berpikir induktif dengan metode probing-prompting learning yang terdiri dari tiga tahap, yaitu pembentukan konsep, interpretasi data, dan penerapan prinsip. SAP disusun untuk tiga pertemuan. LKM disusun untuk meningkatkan kemampuan argumentasi mahasiswa melalui penggunaan pertanyaan-pertanyaan yang menggali dan menuntun gagasan atau ide mahasiswa. Pertanyaan-pertanyaan yang diajukan mengacu pada komponen argumentasi McNeill \& Krajcik yaitu claim, evidence, reasoning dan rebuttal.

Teknik pengumpulan data yang digunakan dalam penelitian ini adalah teknik tes. Teknik tes digunakan untuk mendapatkan data tentang kemampuan argumentasi mahasiswa dalam membuktikan masalah subgrup. Tes dilakukan sebanyak dua kali, yaitu sebelum mahasiswa mengikuti perkuliahan menggunakan model berpikir induktif dengan metode probing-prompting learning (pretest) dan sesudahnya (postest). Pretest digunakan untuk mendapatkan data kemampuan argumentasi awal mahasiswa, sedangkan posttest digunakan untuk mendapatkan data kemampuan argumentasi akhir mahasiswa.

Instrumen yang digunakan dalam penelitian ini adalah lembar tes kemampuan argumentasi. Lembar tes kemampuan argumentasi terdiri dari tiga butir soal uraian untuk membuktikan suatu subgrup finit dan infinit. Setiap butir soal terdiri dari 4 sub butir soal yang didesain berdasarkan komponen argumentasi McNeill \& Krajcik yaitu claim, evidence, reasoning, dan rebuttal. Untuk setiap sub butir soal diberi skor 3 jika mahasiswa menjawab claim, evidence, reasoning, dan rebuttal benar dan lengkap, skor 2 jika mahasiswa menjawab dengan tidak lengkap, dan skor 1 jika mahasiswa tidak menjawab atau memberi jawaban yang tidak relevan dengan soal. Sebelum digunakan instrumen tersebut divalidasi dengan meminta masukan dari ahli, yaitu dosen Pendidikan Matematika Universitas Islam Negeri Sunan Ampel Surabaya.

Analisis data kemampuan argumentasi mahasiswa ditentukan berdasarkan total skor tes yang diperoleh kemudian dikategorikan berdasarkan kriteria pada Tabel 1. 
Tabel 1. Kriteria Kemampuan Argumentasi Mahasiswa

\begin{tabular}{ll}
\hline Rentang Skor & Kriteria \\
\hline $30 \leq N A \leq 36$ & Sangat Baik \\
$24 \leq N A<30$ & Baik \\
$18 \leq N A<24$ & Cukup Baik \\
$12 \leq N A<18$ & Kurang Baik \\
\hline
\end{tabular}

Keterangan:

NA = Total skor kemampuan argumentasi yang diperoleh mahasiswa

Analisis data peningkatan kemampuan argumentasi mahasiswa sebelum dan sesudah mengikuti pembelajaran yang menerapkan model berpikir induktif dengan metode probing-prompting learning dilakukan dengan membandingkan skor pretest dan posttes. Selanjutnya untuk menguji apakah perbedaan antara skor pretest dan posttest tersebut signifikan, maka akan dilakukan uji statistik menggunakan uji Wilcoxon Signed-Rank Test. Pemilihan jenis uji ini dikarenakan distribusi data yang tidak normal, sehingga uji statistik yang dipilih yaitu uji statistik non parametrik. Proses analisis data menggunakan bantuan perangkat lunak SPSS pada taraf signifikan $5 \%(\alpha=$ 0.05). Hipotesis penelitian yang diajukan adalah terdapat perbedaan yang signifikan antara skor kemampuan argumentasi sebelum dan sesudah diterapkannya model model berpikir induktif dengan metode probingprompting learning. Jika skor kemampuan argumentasi mahasiswa setelah perlakuan lebih tinggi dibandingkan sebelum perlakuan dan perbedaannya signifikan, maka penerapan model berpikir induktif dengan metode probing-prompting learning dianggap efektif untuk meningkatkan kemampuan argumentais mahasiswa.

\section{HASIL DAN PEMBAHASAN}

Hasil analisis data tes kemampuan argumentasi mahasiswa dalam menyelesaikan masalah pembuktian pada materi subgrup dapat dilihat pada Tabel 2.

Tabel 2. Sebaran Kemampuan Argumentasi Mahasiswa

\begin{tabular}{lll}
\hline Kriteria Kemampuan & \multicolumn{2}{l}{ Sebaran Mahasiswa (\%) } \\
\cline { 2 - 3 } Argumentasi Mahasiswa & Sebelum Perlakuan & Setelah Perlakuan \\
\hline Sangat baik & 0 & 10,81 \\
Baik & 21,62 & 40,54 \\
Cukup Baik & 54,05 & 43,24 \\
Kurang Baik & 24,32 & 5,4 \\
\hline
\end{tabular}

Tabel 2 menunjukkan bahwa mayoritas kemampuan argumentasi awal mahasiswa termasuk pada kategori cukup baik, namun masih terdapat $24,32 \%$ mahasiswa yang memiliki kemampuan argumentasi kurang baik. Adapun setelah mengikuti perkuliahan yang menggunakan model berpikir induktif dengan metode probing-prompting learning tampak bahwa mahasiswa yang termasuk dalam kategori baik mengalami peningkatan sebesar $18,9 \%$ dan yang termasuk kategori sangat baik meningkat sebesar $10,81 \%$.

Selanjutnya, capaian kemampuan argumentasi mahasiswa dari hasil analisis uji Wilcoxon Signed Rank dapat dilihat pada Tabel 3.

Tabel 3. Ranks Kemampuan Argumentasi Mahasiswa

\begin{tabular}{lllll}
\hline & & $N$ & Mean Rank & Sum of Ranks \\
\hline Postest-Pretest & Negative Ranks & $5^{\mathrm{a}}$ & 14,60 & 73,00 \\
& Positive Ranks & $30^{\mathrm{b}}$ & 18,57 & 557,00 \\
& Ties & $2^{\mathrm{c}}$ & & \\
& Total & 37 & & \\
\hline
\end{tabular}

Keterangan:
a. Postest < Pretest
b. Postest $>$ Pretest
c. Postest $=$ Pretest 
Pada Tabel 3 tampak bahwa terdapat 5 mahasiswa yang mengalami penurunan skor kemampuan argumentasi dari pretest ke posttest (Negatife Ranks). Mean rank atau rata-rata untuk kelompok yang mengalami penurunan skor sebesar 14,6. Namun data pada Tabel 3 juga menunjukkan bahwa terdapat 30 mahasiswa yang mengalami peningkatan skor kemampuan argumentasi dari pretest ke posttest (Positive Ranks). Mean rank atau rata-rata untuk kelompok yang mengalami peningkatan kemampuan argumentasi yaitu sebesar 18,57. Di sisi lain, mahasiswa yang memiliki skor kemampuan argumentasi yang sama antara pretest dan posttest yaitu sebanyak 2 orang. Berdasarkan data tersebut, dapat disimpulkan bahwa lebih banyak mahasiswa yang mengalami peningkatan skor kemampuan argumentasi setelah mengikuti perkuliahan menggunakan model berpikir induktif dengan metode probing-prompting learning.

Selanjutnya berdasarkan output uji statistik pada Tabel 4 diperoleh nilai statistik $Z=-3,973$ dan $p$-value atau Asymp.Sig (2-tailed) yaitu 0,000 yang berarti nilai $p<0,05$, sehingga tidak cukup bukti untuk menerima hipotesis nol. Dengan demikian dapat disimpulkan bahwa terdapat perbedaan signifikan kemampuan argumentasi mahasiswa antara sebelum dan setelah diterapkannya model berpikir induktif dengan metode probing-prompting learning pada perkuliahan.

Tabel 4. Hasil Wilcoxon Signed Ranks Test

\begin{tabular}{ll}
\hline & Postest - Pretest \\
\hline$Z$ & $-3,973^{\mathrm{a}}$ \\
Asymp. Sig. (2-tailed) & 0,000 \\
\hline
\end{tabular}

Keterangan:

a. Based on negative ranks.

Selain untuk mendapatkan data mengenai peningkatan kemampuan argumentasi mahasiswa sebagai akibat penerapan model berpikir induktif dengan metode probing-prompting learning, hasil dari tes kemampuan argumentasi mahasiswa juga dapat digunakan untuk mendapatkan data tentang kemampuan mahasiswa di setiap komponen argumentasi. Deskripsi kemampuan penguasaan komponen argumentasi yang pertama yaitu kemampuan mahasiswa dalam mengajukan claim disajikan pada Tabel 5.

Tabel 5. Kemampuan Mahasiswa dalam Pengajuan Claim

\begin{tabular}{llll}
\hline \multirow{2}{*}{ Skor } & \multirow{2}{*}{ Kriteria Komponen Claim } & \multicolumn{2}{c}{ Sebaran Mahasiswa (\%) } \\
\cline { 3 - 4 } & & Sebelum & Sesudah \\
\hline 3 & Mengajukan claim dengan benar & 66,67 & 62,16 \\
2 & Mengajukan claim yang salah & 31,53 & 34,23 \\
1 & Tidak mampu mengajukan claim & 1,8 & 3,61 \\
\hline
\end{tabular}

Tabel 5 menunjukkan bahwa tidak terdapat perbedaan yang terlalu kontras antara kemampuan awal dan akhir mahasiswa dalam mengajukan claim. Mayoritas mahasiswa mampu mengajukan claim dengan benar. Mahasiswa sudah mampu mengajukan claim dengan benar pada permasalahan pembuktian subgrup finit maupun subgrup infinit. Claim atau dugaan diajukan sebelum mahasiswa menyusun bukti-bukti matematisnya. Oleh karena itu, dalam kasus subgrup, ketepatan pengajuan claim salah satunya bergantung kepada ketepatan dalam mengidentifikasi dengan cepat apakah himpunan-himpunan yang ditanyakan merupakan grup atau tidak. Jika mahasiswa memahami materi grup dengan baik maka mereka akan memiliki pengetahuan terkait contoh-contoh grup. Pada penelitian ini himpunan-himpunan yang ditanyakan di lembar tes argumentasi sudah dipelajari oleh mahasiswa sebelumnya pada perkuliahan materi grup. Sehingga, mahasiswa mudah untuk mengenali apakah himpunan tersebut grup atau tidak. Selanjutnya mahasiswa hanya perlu memeriksa apakah himpunan yang mau dibuktikan sebagai subgrup merupakan himpunan bagian dari grupnya. Adapun untuk kelompok mahasiswa yang salah dalam mengajukan claim, mayoritas kesalahan terjadi ketika diminta untuk membuktikan suatu struktur aljabar yang bukan subgrup. Mahasiswa gagal mengidentifikasi bahwa salah satu syarat dari subgrup adalah memiliki kesamaan operasi dengan grupnya. Mahasiswa hanya terfokus untuk mengidentifikasi apakah himpunannya merupakan grup terhadap operasi yang diberikan, tetapi lupa untuk memperhatikan kesamaan operasi dengan grupnya.

Setelah mengajukan claim maka mahasiswa diminta untuk menyusun bukti (evidence) yang mendukung claim. Hasil dari analisis data kemampuan mahasiswa dalam menyusun bukti (evidence) dapat dilihat pada Tabel 6 . 
Tabel 6. Kemampuan Mahasiswa Menyusun Evidence (Bukti)

\begin{tabular}{|c|c|c|c|}
\hline \multirow{2}{*}{ Skor } & \multirow{2}{*}{ Kriteria Komponen Evidence } & \multicolumn{2}{|c|}{ Sebaran Mahasiswa (\%) } \\
\hline & & Sebelum & Sesudah \\
\hline 3 & $\begin{array}{l}\text { Menyusun bukti dengan benar dan lengkap } \\
\text { untuk mendukung claim }\end{array}$ & 20,72 & 29,73 \\
\hline 2 & $\begin{array}{l}\text { Menyusun bukti yang kurang lengkap untuk } \\
\text { mendukung claim }\end{array}$ & 29,73 & 49,55 \\
\hline 1 & $\begin{array}{l}\text { Tidak mampu menyusun bukti atau bukti tidak } \\
\text { relevan untuk mendukung claim }\end{array}$ & 49,55 & 20,72 \\
\hline
\end{tabular}

Berdasarkan Tabel 6 terlihat bahwa secara umum kemampuan awal mahasiswa dalam menyusun bukti masih rendah. Mayoritas mahasiswa tidak mampu menyusun bukti atau menyusun bukti yang tidak relevan untuk mendukung claim yaitu dengan persentase sebesar $49,55 \%$. Hal ini tentunya bertolak belakang dengan kemampuan mereka dalam mengajukan claim. Kondisi ini menunjukkan bahwa mahasiswa mengajukan claim tanpa dasar atau ada unsur asal-asalan. Setelah mengikuti perkuliahan yang menggunakan model berpikir induktif dengan metode probing-prompting learning, kemampuan mahasiswa dalam menyusun bukti tampak mengalami perubahan. Sebanyak 49,55\% mahasiswa sudah mampu menyusun bukti yang mendukung claim sekalipun belum lengkap. Selain itu sebanyak 29,73\% mahasiswa telah mampu menyusun bukti dengan benar dan lengkap.

Kemampuan menyusun bukti sangat terkait dengan kemampuan penguasaan konsep. model berpikir induktif telah membantu mahasiswa memahami konsep subgrup melalui proses pembentukan konsep dan interpretasi data. Selanjutnya menerapkan prinsip yang diperlukan untuk menyelesaikan situasi baru. Pada saat proses pembentukan konsep, kemampuan koneksi matematis mahasiswa juga akan dilatih. Kemampuan koneksi matematis ini akan membantu mahasiswa mengkaitkan pengetahuan yang telah dimiliki, dalam kasus ini konsep grup, untuk menyelesaikan pembuktian subgrup. Di lain pihak, metode probing- prompting learning dapat digunakan meningkatkan kemampuan koneksi matematis melalui pemberian pertanyaan-pertanyaan menggali dan menuntun, sesuai dengan hasil penelitian Danaryanti \& Tanaffasa (2016).

Kendati demikian, masih terdapat 20,72\% mahasiswa yang belum mampu menyusun bukti atau menyusun bukti yang tidak relevan. Kesalahan yang terjadi dalam penyusunan bukti ini biasanya terletak pada ketidakmampuan dalam memanipulasi simbol-simbol aljabar untuk membuktikan syarat-syarat subgrup terutama pada pembuktian subgrup infinit. Walaupun memiliki pemahaman yang baik tentang konsep subgrup, namun keterampilan dalam memanipulasi simbol aljabar juga mempengaruhi ketepatan penyusunan bukti matematis. Selain itu, ketidaktepatan dalam pengelolaan waktu penyelesaian masalah juga menjadi penyebab mahasiwa tidak mampu menyusun bukti dengan optimal. Mahasiswa pada umumnya terlalu fokus untuk menyelesaikan dua masalah pembuktian sehingga tidak menyadari kalau waktu pengerjaan semakin sedikit untuk menyelesaikan masalah ketiga.

Ketidakmampuan mahasiswa dalam menyusun evidence yang tepat juga terlihat dalam masalah pembuktian bukan subgrup. Hal ini karena mereka sudah terlanjur memiliki dugaan yang salah. Mayoritas mahasiswa tidak mampu untuk menyusun kontra-argumentasi atau sanggahan pada kasus-kasus seperti ini. Jika dihadapkan dengan masalah pembuktian mahasiswa cenderung mengajukan claim yang membenarkan pernyataan tersebut, tanpa mengidentifikasi lebih mendalam apakah operasi yang diberlakukan sama ataukah setiap anggota himpunan memenuhi syarat-syarat yang ditentukan. Kondisi ini sejalan dengan pendapat Stein dan Bernas (1999) yang menyatakan bahwa mahasiswa lemah dalam menyusun kontra-argumentasi. Oleh karena itu, pemberian pertanyaan-pertanyaan dalam LKM yang menggali kemampuan mahasiswa dalam mengidentifikasi operasi dan karakteristik dari setiap anggota himpunan terhadap operasi yang berlaku padanya harus ditingkatkan.

Bukti yang telah disusun harus didasarkan pada teorema yang tepat. Kemampuan pemilihan teorema yang tepat ini termasuk dalam komponen reasoning. Tabel 7 menunjukkan hasil analisis data kemampuan mahasiswa pada komponen reasoning. Sejalan dengan kemampuan awal mahasiswa dalam menyusun bukti, berdasarkan Tabel 7, kemampuan awal mahasiswa dalam memilih alasan juga belum baik. Mayoritas mahasiswa yaitu sebanyak $54,05 \%$ tidak mampu menunjukkan alasan atau tidak memberi alasan yang relevan dengan permasalahan yang dihadapi. Namun, setelah mengikuti model berpikir induktif dengan metode probing-prompting learning tampak tidak terdapat perubahan yang signifikan. Sebanyak $45,94 \%$ mahasiswa tetap tidak dapat memberi alasaan yang benar. Hal ini menunjukkan bahwa walaupun mampu menyusun bukti dengan baik, tetapi terkadang mahasiswa 
masih ragu apakah alasan yang diberikan sudah sesuai untuk menjawab permasalahan yang diberikan atau mahasiswa hanya mengikuti contoh yang sudah ada tanpa mengetahui alasannya.

Tabel 7. Kemampuan Mahasiswa Memilih Alasan (Reasoning)

\begin{tabular}{llll}
\hline \multirow{2}{*}{ Skor } & \multirow{2}{*}{ Kriteria Komponen Reasoning } & \multicolumn{2}{l}{ Sebaran Mahasiswa (\%) } \\
\cline { 3 - 4 } & Menjelaskan alasan yang relevan dengan & Sesudah \\
\hline 3 & $\begin{array}{l}\text { claim dan bukti yang disusun dengan benar } \\
2\end{array}$ & $\begin{array}{l}\text { Menjelaskan alasan pengajuan claim dan bukti } \\
\text { tetapi kurang lengkap }\end{array}$ & 26,13 \\
\multirow{2}{*}{$\begin{array}{l}\text { Tidak mampu menunjukkan alasan atau } \\
\text { alasan tidak relevan }\end{array}$} & 54,05 & 27,93 \\
\hline
\end{tabular}

Kemampuan terakhir dalam komponen argumentasi adalah kemampuan mahasiswa menyusun rebuttal. Tabel 8 menyajikan sebaran mahasiswa berdasarkan kemampuannya dalam menyusun rebuttal.

Tabel 8. Kemampuan Mahasiwa Menyusun Rebuttal

\begin{tabular}{llll}
\hline \multirow{2}{*}{ Skor } & \multirow{2}{*}{ Kriteria Komponen Rebuttal } & \multicolumn{2}{l}{ Persentase Mahasiswa (\%) } \\
\cline { 3 - 4 } & Awal & Akhir \\
\hline 3 & Menyusun alternatif bukti dengan benar & 0 & 9,91 \\
2 & $\begin{array}{l}\text { Menyusun alternatif bukti namun tidak } \\
\text { lengkap }\end{array}$ & 2,7 & 15,32 \\
1 & Tidak mampu menyusun alternatif bukti & 97,3 & 74,77 \\
\hline
\end{tabular}

Berdasarkan Tabel 8 tampak bahwa kemampuan awal mahasiswa dalam menyusun rebuttal sangat kurang. Seluruh mahasiswa tidak bisa menyusun rebuttal dengan benar dari ketiga masalah pembuktian yang diberikan. Kurangnya pengetahuan tentang konsep subgrup membuat mahasiswa tidak bisa menuliskan alternatif jawaban lain untuk masalah yang terbukti subgrup atau memberi sanggahan (kontra argumentasi) yang sesuai untuk masalah yang bukan subgrup. Setelah penerapan perkuliahan yang menggunakan model berpikir induktif dengan metode probing-prompting learning, tampak bahwa kemampuan mahasiswa dalam menyusun rebuttal sudah semakin baik. Terdapat peningkatan sebesar 9,91\% mahasiswa yang telah mampu menyusun alternatif bukti dengan benar dan $15,32 \%$ mahasiswa juga telah mencoba menyusun alternatif bukti walaupun tidak lengkap.

Kemampuan mahasiswa dalam menyusun rebuttal perlu untuk ditingkatkan disini. Masih ada $74,77 \%$ mahasiswa yang tidak dapat memberikan alternatif jawaban. Padahal pada materi subgrup ini sangat memungkinkan untuk menggunakan bervariasi teorema dalam penyelesaian masalahnya. Selama proses perkuliahan mahasiswa sudah diminta untuk memberikan alternatif jawaban lain dari permasalahan tentang subgrup ini terutama melalui LKM. Dalam kasus ini, penyebab rendahnya kemampuan siswa pada komponen tersebut setidaknya ada tiga. Pertama, telah dijelaskan sebelumnya bahwa mahasiswa tidak mampu mengatur waktu dengan baik. Penyebab yang kedua karena mahasiswa belum mampu mengaplikasikan berbagai teorema subgrup untuk menyelesaikan masalah. Sedangkan penyebab yang ketiga karena mahasiswa lupa bunyi teorema subgrup.

Secara umum, model berpikir induktif dengan metode probing-prompting learning dapat digunakan sebagai alternatif pembelajaran untuk meningkatkan kemampuan argumentasi mahasiswa pada materi subgrup. Selain itu, model berpikir deduktif dengan metode probing-prompting learning ini juga perlu dicobakan pada mata kuliah lainnya, terutama untuk mata kuliah yang memerlukan analisis dan kemampuan berpikir kritis. Terkait keterbatasan dalam penelitian ini, perbaikan terhadap perangkat pembelajaran terutama LKM perlu dilakukan, terutama penambahan permasalahan yang dapat melatihkan pengajuan kontra argumentasi atau sanggahan.

\section{SIMPULAN}

Berdasarkan hasil penelitian dan pembahasan, diperoleh beberapa hal yang menjadi simpulan dalam penelitian ini. Pertama, kemampuan argumentasi mayoritas mahasiswa sebelum mengikuti perkuliahan yang menerapkan model berpikir induktif dengan metode probing-prompting learning termasuk dalam kategori cukup baik. Mayoritas mahasiswa mampu mengajukan claim dengan benar, namun tidak mampu menyusun bukti, memilih 
alasan dan menyusun rebuttal yang benar dan lengkap. Kedua, setelah mengikuti perkuliahan dengan diterapkannya model berpikir induktif dengan metode probing-prompting learning, kemampuan argumentasi mayoritas mahasiswa termasuk dalam kategori sangat baik dan baik. Mahasiswa mampu mengajukan claim dengan benar. Selain itu, persentase mahasiswa yang mampu menyusun bukti, memilih alasan dan menyusun rebuttal dengan benar dan lengkap mengalami peningkatan. Ketiga, kemampuan argumentasi mahasiswa setelah perlakuan lebih baik dibandingkan sebelum perlakuan dan terdapat perbedaan signifikan $(Z=-7,3973, p=0,000)$ kemampuan argumentasi mahasiswa sebelum dan setelah diterapkan model berpikir induktif dengan metode probing-prompting learning pada materi subgrup. Dengan demikian, penerapan model berpikir induktif dengan metode probingprompting learning pada materi subgrup efektif untuk meningkatkan kemampuan argumentasi mahasiswa.

Terdapat beberapa saran yang dapat diajukan berdasarkan temuan dalam penelitian ini. Pertama, model berpikir induktif dengan metode probing-prompting learning hendaknya dijadikan sebagai salah satu model pembelajaran yang rutin digunakan oleh dosen untuk mengajar mata kuliah struktur aljabar. Kedua, kepada peneliti lain hendaknya dapat melakukan penelitian serupa dengan melibatkan kelas kontrol, sehingga efektivitas dari perlakuan yang diberikan benar-benar menggambarkan situasi di lapangan. Ketiga, hendaknya dilakukan penelitian serupa dengan melibatkan populasi dan sampel yang lebih luas lagi, sehingga memungkinkan generalisasi yang lebih luas.

\section{DAFTAR PUSTAKA}

Bell, F. H. (1981). Teaching and learning mathematics in secondary schools. Debuque, IA: Wm. C. Brown Company Publisher.

Chin, E. T. (2003). Mathematical proof as formal process in advanced mathematical thinking. Retrieved from http://www.lettredelapreuve.org/OldPreuve/PME/PME27/RR_chin.pdf

Danaryanti, A., \& Tanaffasa, D. (2016). Penerapan Model Probing Prompting Learning Untuk Meningkatkan Kemampuan Koneksi Matematis Siswa SMP. EDU-MAT Jurnal Pendidikan Matematika, 4(1), 8-14. doi: http://dx.doi.org/10.20527/edumat.v4i1.2283

Ennis, R. (1981). Critical thinking. Upper Saddle River, NJ: Prentice-Hall.

Farida, I., \& Gusniarti, W. F. (2014). Profil keterampilan argumentasi siswa pada konsep koloid yang dikembangkan melalui pembelajaran inkuiri argumentatif. EDUSAINS, 6(1), 31-40. doi: https://doi.org/10.15408/es.v6i1.1098

Gumelar, F. (2016). Efektivitas metode probing prompting learning dalam pembelajaran menulis argumentasi. Riksa Bahasa: Jurnal Bahasa, Sastra, dan Pembelajarannya, 2(2), 168-173. Retrieved from http://ejournal.upi.edu/index.php/RBSPs/article/view/9557

Huang, R. (2005). Verification or proof: Justification of pythagoras' theorem in chinese mathematics classroom. In Chick, H. L. \& Vincent, J. L. (Eds.), Proceedings of the 29th Conference of the International Group for the Psychology of Mathematics Education (pp. 161-168). Melbourne: PME. Retrieved from https://www.emis.de/proceedings/PME29/PME29RRPapers/PME29Vol3Huang.pdf

Huda, M. (2017). Model-model pengajaran dan pembelajaran: Isu-isu metodis dan paradigmatis. Yogyakarta: Pustaka Pelajar.

Inglis, M., Ramos, J. M., \& Simpson, A. (2007). Modelling mathematical argumentation: The importance of qualification. Educational Studies in Mathematics, 66(1), 3-21. doi: https://doi.org/10.1007/s10649-0069059-8

McNeill, K. L., \& Krajcik, J. (2011). Suporting grade 5-8 students in constructing explanation in science. London, UK: Pearson.

Meghan, B., Crowell, A., Schunn, C., Cannady, M., \& Dorph, R. (2015). The learning benefits of being willing and able to engage in scientific argumentation. International Journal of Science Education, 37(10), 1590-1612. https://doi.org/10.1080/09500693.2015.1045958 
Newton, P., Driver, R., \& Osborne, J. (1999). The place of argumentation in the pedagogy of school science. International Journal of Science Education, 21(5), 553-576. doi: https://doi.org/10.1080/095006999290570

Ruggiero, V. R. (2009). Becoming a critical thinker. Boston, MA: Houghton Mifflin Company.

Shirley, S., Erduran, S., \& Osborne, J. (2006). Learning to teach argumentation: Research and development in the science classroom. International Journal of Science Education, 28(2), 235-260. doi: https://doi.org/10.1080/09500690500336957

Siakad UIN Sunan Ampel. (2017). Retrieved from http://siakad.uinsby.ac.id/akademik/siakad/index.php? page=list_nilai

Soedjadi, R. (1998). Kiat pendidikan matematika di indonesia: konstatansi keadaan masa kini menuju harapan masa depan. Jakarta: Departemen Pendidikan dan Kebudayaan Direktorat Jenderal Pendidikan Tinggi.

Soekisno, R. A. (2015). Pembelajaran berbasis masalah untuk meningkatkan kemampuan argumentasi matematis mahasiswa. Infinity Jurnal IImiah Program Studi Matematika STKIP Siliwangi Bandung, 4(2), 120-139. doi: https://doi.org/10.22460/infinity.v4i2.p120-139

Stein, N., \& Bernas, R. (1999). The early emergence of argumentative knowledge and skill. Amsterdam, Netherland: Amsterdam University Press.

Sumaryati, E., \& Sumarmo, U. (2013). Pendekatan induktif-deduktif disertai strategi think-pair-square-share untuk meningkatkan kemampuan pemahaman dan berpikir kritis serta disposisi matematis siswa SMA. Infinity Journal, 2(1), 26-42. doi: https://doi.org/10.22460/infinity.v2i1.p26-42

Tristanti, L. B., Sutawidjaja, A., As'ari, A. R., \& Muksar, M. (2015). Modelling student mathematical argumentation with structural-intuitive and deductive warrant to solve mathematics problem. Procedings ICERD 2015 (pp.130-139). Surabaya: The State University of Surabaya.

Zeidler, D. L. (1997). The central role of fallacious thinking in science education. Science Education, 81(4), 483-496. doi: https://doi.org/10.1002/(SICI)1098-237X(199707)81:4<483::AID-SCE7>3.0.CO;2-8 